\title{
V-Prechop nucleodissection technique feasibility in the phacoemulsification in dogs with cataracts. Clinical aspects and specular microscopy
}

\section{Exequibilidade da técnica V-Prechop de nucleodissecção na facoemulficação em cães com catarata. Aspectos clínicos e microscopia especular}

\author{
Alexandre Lima de Andrade ${ }^{1 *}$; Luciano Fernandes da Conceição ${ }^{2}$; \\ Adriana Morales'2; Ivan Ricardo Martinez Padua²; José Luiz Laus ${ }^{3}$
}

Highlights:

There was not description of the V-prechop technique in the literature.

The post-operative complications were less frequent in patients with immature cataract.

There was the decrease of the endothelium cells in animals with mature cataract.

The postoperative ophthalmic signs were more pronounced in patients with mature cataract.

The nucleodissection "V-prechop" is indicated in selected cases of patients with immature cataracts.

\begin{abstract}
The aim of this study was to evaluate the feasibility of the V-Prechop nucleodissection technique in the phacoemulsification in dogs and the clinical aspects and of the specular microscopy in the postoperative period. Fourty three dogs of different breeds, males and females, aged 3 to 10 years, with mature $(n=22)$ and immature $(\mathrm{n}=21)$ cataracts were used. After surgery, patients were evaluated weekly for visual acuity, intraocular pressure, and endothelial corneal cell density (by non-contact specular microscopy) and quantitative flare (by laser flare photometry) during different periods. The "V-prechop" technique presented technical difficulties in implementation in patients with a mature cataract. In selected cases of patients with an immature cataract, the technique can be employed, as the nuclei are softer, allowing confection of the linear fragments in "V" to be performed. In addition, the eyes of dogs with a mature cataract presented more intensive postoperative uveitis, probably related to the greater difficulty in conducting the "V" nucleodissection. There was decreased endothelial corneal cell density in dogs with mature and immature cataracts. This occurrence was greater in patients with a mature cataract, given the increased intraocular manipulation and surgical time due to the difficulty in performing the "V" nucleodissection. According to the results obtained, the "V-prechop" nucleodissection technique can be indicated in selective cases of dogs with an immature cataract.
\end{abstract}

Key words: Dogs. Cataract. Nucleodissection. V-prechop. Specular microscope.

1 Prof. Dr. , Departamento de Clínica, Cirurgia e Reprodução Animal, Faculdade de Medicina Veterinária de Araçatuba, FMVA, UNESP, Araçatuba, SP, Brasil. E-mail: al.andrade@unesp.br

2 Drs. em Cirurgia Veterinária, Faculdade de Ciências Agrárias e Veterinárias de Jaboticabal, FCAVJ, UNESP, Jaboticabal. SP, Brasil. E-mail: luciano_oftalmovet@hotmail.com; drimorales@gmail.com; ivanrimarpa@gmail.com

3 Prof. Titular, Departamento de Clínica e Cirurgia Veterinária, FCAVJ, UNESP, Jaboticabal. SP, Brasil. E-mail: jllaus@unesp.br

* Author for correspondence

Received: May 20, 2019 - Approved: Oct. 05, 2020 


\section{Resumo}

O objetivo deste estudo foi avaliar a viabilidade da técnica V-Prechop de nucleodissecção na facoemulsificação em cães e os aspectos clínicos e de microscopia especular no período pós-operatório. Quarenta e três cães de diferentes raças foram utilizados, machos e fêmeas, com idade entre três a dez anos e portadores de cataratas maduras $(n=22)$ e imaturas $(n=21)$. Após a cirurgia, os pacientes foram avaliados semanalmente quanto à acuidade visual, pressão intraocular e densidade celular endotelial da córnea (por microscopia especular sem contato) e quantitativo de flare (por flarefotometria a laser), em diferentes períodos. A técnica "V-prechop" revelou dificuldades técnicas em pacientes com catarata madura. Em casos selecionados de pacientes com uma catarata imatura, a técnica pode ser empregada, pois os núcleos são menos densos, o que permitiu a confecção dos fragmentos lineares em "V". Além disso, os olhos de cães com uma catarata madura apresentaram uveíte posoperatória mais intensa, provavelmente relacionada à maior dificuldade em conduzir a confecção das fraturas em "V". Houve diminuição da densidade das células corneais endoteliais cães com catarata madura e imatura. Essa ocorrência foi mais pronunciada em pacientes com uma catarata madura, devido a maior manipulação cirúrgica intraocular e tempo cirúrgico, pois houve maior dificuldade técnica em realizar a confecção dos fragmentos em "V". De acordo com os resultados obtidos, a técnica de nucleodissecção "V-prechop" pode ser indicada em casos seleconados de cães com catarata imatura.

Palavras-chave: Cães. Catarata. Nucleodissecção. V-prechop. Microscopia especular.

\section{Introduction}

Cataracts are the leading cause of vision loss in dogs, affecting both crossbred and pure breed animals (Glover \& Constantinescu, 1997; La Croix, 2008; Wilkie \& Colitz, 2007; Park et al., 2009). The only therapeutic approach, in humans and in animals, is surgical (Fischer, 1989; Dziezyc, 1990; La Croix, 2008; Resnikoff et al., 2004), although Zhao et al. (2015) have described that lanosterol decreases the aggregates of lenticular proteins and reduces the chances of cataract evolution, pointing it as a new treatment strategy. In the veterinary cataract surgery has evolved from extracapsular extraction to phacoemulsification ( $\mathrm{La}$ Croix, 2008; Padua et al., 2017). The advances are unquestionable, and more alternatives are being sought to further improve the methods. Different techniques for extracapsular cataract extraction, with or without implantation of intraocular lenses, have been proposed. Variations in extracapsular techniques have been described in order to decrease postoperative complications. Currently the preferred procedure is phacoemulsification, which constitutes lens ultrasonic fragmentation, with subsequent aspiration of emulsified material through a small incision in the clear cornea (Glover \& Constantinescu, 1997; Centurion, Lacava, \& Caballero, 2004; Resnikoff et al., 2004; Zhao et al., 2015; Nasisse et al., 1991; Bistner, 1992; Wilkie \& Colitz, 2007; La Croix, 2008).

Among the various phacoemulsification procedures described, the technique of "Divide and Conquer" is the most suitable for beginners. Although not the most efficient, there is consensus that it is safer for surgeons during the learning curve. Nagahara cited by Can, Takmaz, Çakici, Özgül and Meltem (2004) introduced a technical variant that performs a "lens chop" (fracture) with the aid of a second instrument, for a service incision, called the "phaco-chop" technique. It considers a cleavage plane situated between the outer layer and "inner core" for the anatomical division of the nucleus, denominated nucleodissection (Warren, 2004).

One of the recent advances refers to the technique of "prechop", which uses a "prechopper" to perform two perpendicular fractures, one on the other, dividing the lens into quadrants (Akahoshi, 1998; Warren, 2004). However, the procedure cannot be 
applied in all cases. The most common complications are related to conditions of lens adhesion to the posterior capsule in which the hydrodissection may be inefficient, generating difficulties in promoting rotation of the nucleus, with loss of anterior chamber depth, since excessive irrigation promotes the expulsion of the viscoelastic substance. When such complications occur, it becomes impractical to continue the technique. Another complication arises from the non-visualization of the cortex, which can break down during the first fracture, at the time of the nucleus rotation. Cortical remnants mix with the viscoelastic substance, clouding the anterior chamber and preventing the second fracture from being safely performed.

In nuclei with varying degrees of hardness, oblique fractures may occur in relation to the fibrillar structure, allowing construction of one fragment in a "V", thus eliminating the need to obtain a free nucleus. This dispenses with performance of the two steps of rotation, practiced in the "prechop" technique. Furthermore, the hydrodissection can be carried out after fracture, making use of liquid pressure to carry the projection of the fragment in a "V" to the pupillary plane, facilitating emulsification. This technique is called "V-prechop". The evaluation of postoperative clinical parameters may help to predict whether or not the technique is proposed, as well as specular microscopy (Munger, 2009; Pigatto et al., 2006; Padua et al., 2017).

Faced with this contingent of technique variations for cataract surgery and no consensus, it seems appropriate to consider new surgical alternatives, added to which there is currently no description of this technique in the literature. Thus, the aim of this study was to evaluate the feasibility, advantages, and complications of phacoemulsification through the $V$-prechop technique of nucleus dissection in dogs, evaluating the ocular signs, and alterations in the quantity of corneal endothelial cells associated with application of the technique.

\section{Material and Methods}

\section{Ethical consideration}

The study was carried out under the express authorization of the tutors of the animals and of the Committee of Ethics in Animal Experimentation of São Paulo State University (UNESP), School of Agricultural and Veterinarian Sciences, Jaboticabal campus (Protocol 018663-08). Bioethical care was conducted according to the stantards of the Association for Research in Vision and Ophthalmology - ARVO (National Institutes of Health Publications No 85-23: Revised 1985).

\section{Animals}

In all, 43 eyes from 21 dogs were include in the study. Dogs ranged from 3 to 10 years of age, male and female, and were divided into group 1 (G1, immature cataract, $\mathrm{n}=21)$ and group $2(\mathrm{G} 2$, mature cataract, $n=22$ ).

All dogs underwent pupillary light reflex test, the Schirmer tear test (Ophthalmos, São Paulo, Brazil), slit lamp biomicroscopy (SL-15 Kowa Company, Tokyo, Japan), gonioscopy (Koeppe Medium Diagnositc lens $18 \mathrm{~mm}$; Ocular Intruments Inc., Bellevue, Washington, USA), and applanation tonometry (Tonopen XL, Mentor Inc., Norwell, MA, USA) in corneas desensitized with $0.5 \%$ proxymetacaine (AnestalconÒ; Alcon, São Paulo, Brazil), as well as indirect binocular ( $\mathrm{OCH}-3.3$; Opto Eletrônica S.A., São Carlos, Brazil) and direct monocular ophthalmoscopy (7100 -C; Welch Allyn, Mississauga, Ontario, Canada) after pupil dilation with mydriatic and mild cycloplegic (MydriacylÒ, Alcon, São Paulo, Brazil). Fluorescein eye stain test (Fluorescein strips; Ophthalmos, São Paulo, Brazil) was also performed.

Subjective tests for the assessment of visual perception were administered, such as maze, cotton, and dazzle reflex. These were considered together with observations provided by the animal's tutors 
regarding ambulation and objective avoidance. There were included only animals without concurrent abnormalities. Then, general clinical conditions were assessed via physical examination, global count of blood cells, assessment of hepatic and renal functions, and glycemia. Pre-selected animals were submitted to ocular ultrasonography (UltraScan Imaging System; Alcon) in mode A and B. Electroretinography (Handheld Multi-species ERG; Retvetcorp, Columbia, Missouri, USA) in flash and flicker, according to the Dog Diagnostic Protocol (Nafströn et al., 2012), was used in order to identify severe concurrent retinopathy. Only electroretinographically healthy animals were included in the research.

\section{Preoperative therapeutic procedures}

Preoperative therapeutics began before the initial surgical procedures and included administration of one drop of trobramycin $0.3 \%$ and dexamethasone $0.1 \%$ eye drops (TrobadexÒ; Alcon, Brazil) four times daily. One drop of atropine sulfate $1 \%$ (Atropina 1\%Ò; Allergan, São Paulo, Brazil) was administered $30 \mathrm{~min}$ prior to the surgical procedure. A single injection of flunixin meglumine (BanamineÒ; Schering-Plough, São Paulo, Brazil; $1.1 \mathrm{mg} \mathrm{kg}^{-1}$, i.m.) was administered $30 \mathrm{~min}$ prior to surgery.

\section{Anesthetic procedures}

After food and water fasting for 12 and $6 \mathrm{~h}$, respectively, animals were pre-anesthetized with meperidine (DolosalÒ, Cristália, Itapira, Brazil; $0.005 \mathrm{mg} \mathrm{kg}^{-1}$, i.v.) associated with diazepam (DiazepamilÒ, Hipolabor, Belo Horizonte, Brazil; $0.03 \mathrm{mg} \mathrm{kg}^{-1}$ ). After $15 \mathrm{~min}$, general anesthesia was induced with propofol (ProfolenÒ, Blausiegel, São Paulo, Brazil; 5.0mg kg-1, i.v.). Anesthesia was maintained with a halogenate agent (IsoforineÒ, Cristália, São Paulo, Brazil), vaporized in oxygen, in a semi-closed gas re-inhalation circuit. After isolation of the surgicalfield, intravenous rocuronium bromide (EsmeronÒ; Organos, São Paulo, Brazil. $0.3 \mathrm{mg} \mathrm{kg}^{-1}$ i.v.) was utilized for neuromuscular blockade, and automated mechanical ventilation was performed.

\section{Phacoemulsification}

During the cataract surgery, performed bya single surgeon (ALA), animals were kept in the supine position. Only the right eye of each animal was operated on. An aqueous solution of pirrolydone iodine (Laboriodine PVPI topical; Laboratórios Biossintética, São Paulo, Brazil) was used for antisepsis of the eyelids by diluting at a proportion of 1:1 in saline solution (Sodium chloride $0.9 \%$; Baxter Hospitalar, São Paulo, Brazil). The same solution was then diluted at a proportion of 1:50 for the ocular surface. A twohanded phacoemulsification technique was utilized with primary corneal inciosion located $1 \mathrm{~mm}$ from the limbus. The main incision located was tunneled in the 11 o'clock position, with a 3.2-mm angled scalpel (Surgical Knife $3.2 \mathrm{~mm}$; Alcon do Brasil, Brazil). The anterior chamber was filled with a vital dry (Trypan blueÒ; Ophthalmos) for staining the anterior lens capsule.

Chondroitin sulfate $4 \%$, sodium hyaluronate $3 \%$ (ViscoatÒ; Alcon do Brasil), and methylcellulose 2\% (Ophthalmos, São Paulo, Brazil) were used as ophthalmic viscosurgical devices (OVDs) in the 'soft-shell' technique proposed by Arshinoff (1999).

The incision in the anterior lens capsule was made using an angled $3.3 \mathrm{~mm}$ scalpel, followed by continuous curvilinear capsulorhexis (CCC), with Utrata collet (Capsulorhexis Forceps, Ultrata Steel Inox, Guarulhos, Brazil). Hydrodissection was done using a syringe coupled to an irrigation cannula and BSS.

With the aid of an Agahoshi prechopper (Prechopper Agahoshi, Storz Instruments, USA), inserted through the main incision, the 
nucleodissection was carried out, by an oblique fracture followed by a second, in order to form a "V". To facilitate this maneuver a nucleus manipulator was used to exert counterpressure to the Agahoshi prechopper. A second hydrodissection was performed for expulsion of the viscoelastic and projection of the "V" segment were promoted, aimed at phacoemulsification of the nucleus. For cataract surgery, we deployed a phacoemulsifier (Facoemulisificador Universal II - Alcon) using the Legacy pen adapted in the equipment.

The technique proceeded to aspiration of the "V" segment, and then the cortical remnants were aspirated as well as the remaining viscoelastics. To finalize the steps, the principle corneal incision was sutured with two simple separate points, not transfixed and buried, using monofilament nylon thread 9-0 (Mononylon 9-0, Ethicon, USA). Intraocular lenses were not implanted, generating afascia condition. Figure 1 illustrate the steps of the phacoemulsification. At the end of each procedure the following data were recorded: the ultrasound time, quantity of balanced saline solution (BSS) used, and any surgical complications. Findings regarding the opacity of the pre-existing posterior capsule and the intraocular pressure (IOP) were also recorded.

During the surgical procedure, a questionnaire containing questions regarding the stages and the degree of technical difficulty in completing each of the stages of the proposed technique was recorded, which was recorded by an auxiliary assigned to this. The following scores were adopted: none, slight, moderate and severe. 

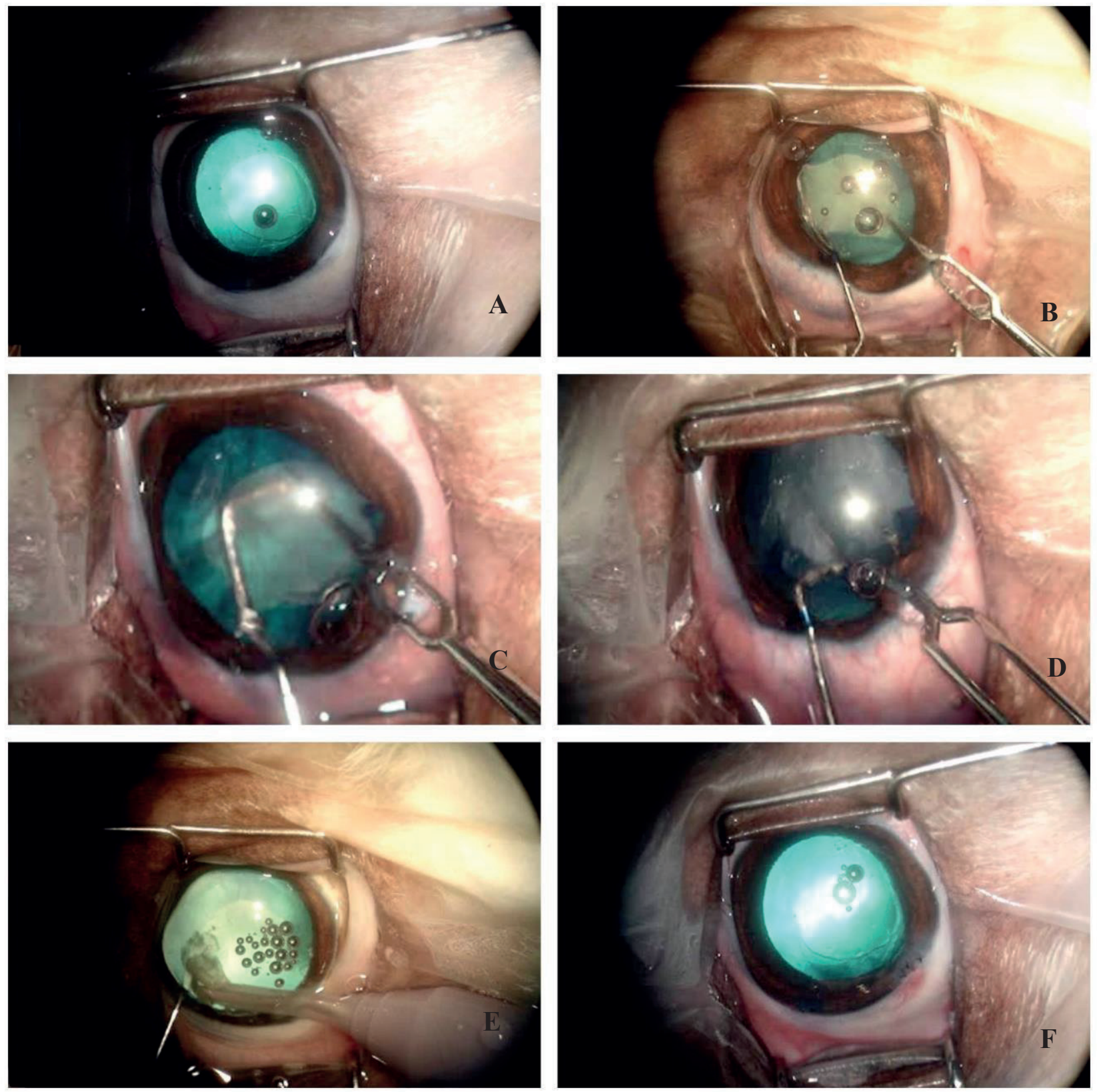

Figure 1. Phacoemulsification by V-prechop technique.

A. Finalized capsulurexis procedure; B. The first line of the "V" segment with Agahoshi prechopper in mature cataract; C. The first line of the "V" segment with Agahoshi prechopper in imature cataract; D. The second line of the "V" segment with Agaroshi prechop in imature cataract; E. phacoemulsification; F. Phacoemulsification concluded without intraocular lens (eye aphacic). 


\section{Postoperative procedures}

Following surgery, patients received systemic prednisone $\quad\left(\right.$ Meticorten $^{\circledR}, \quad$ Schering Ploug, Brazil) (1mg. $\left.\mathrm{kg}^{-1}\right)$ every 24 hours for 15 days, topical dexamethasone associated to tobramycin (Tobradex $^{\circledR}$, Alcon Laboratórios do Brasil AS, Brazil) ( $q 4 \mathrm{~h}$ ) for at least 30 days, 1\% brinzolamide (Azopt $^{\mathbb{Q}}$, Alcon Laboratórios do Brasil AS, Brazil) $(\mathrm{q} 12 \mathrm{~h})$, and $1 \%$ tropicamide (Mydriacyl ${ }^{\circledR}$, Alcon Laboratórios do Brasil AS, Brazil) (q8 h) for up to 7 days. Patients wore an Elizabethan collar for at least 15 days.

\section{Moments and variables of the postoperative clinical evaluation}

Each patient was examined 7, 14, 21, 30, 45 , and 60 days after surgery, by monitoring the intraocular pressure. Subjective tests were also used to evaluate visual perception, such as the maze, cotton, and obfuscation tests, added to observations reported by the owners regarding ambulation and object avoidance. Furthermore, qualitative and quantitative evaluations were recorded and retained on the photophobia and blepharospasm, conjunctival congestion, edema and corneal ulceration, transparency of the aqueous humor, abnormal content in the anterior chamber (flare, hyphema, and hypopyon), posterior lenticular capsule opacity, and the presence of vitreoretinal alterations, following the same criteria used in the ophthalmic examination described above.

\section{Specular microscopy method}

The animals were evaluated immediately following surgery and 7, 14, 21, 30, 45, and 60 days after. Post-operative examinations were performed as previously reported for patient selection. Endothelial conditions were studied by noncontact specular microscopy (SP-3000P ${ }^{\circledR}$, Topcon, Japan) after intravenous anesthesia with propofol (Propovan $^{\circledR}$, Cristália, Brazil) $\left(5 \mathrm{mg} \cdot \mathrm{kg}^{-1}\right)$. In order to avoid variations in the results, all animals were positioned by the same person.

During a previous pilot study, it was found to be difficult to obtain satisfactory images of the corneal endothelium, since the beam of light reflected both in the opaque lens and corneal endothelium. In order to overcome this obstacle, topical latanoprost (Xalacom ${ }^{\circledR}$, Pfizer, Brazil) was administered. The resultant miosis impaired the reflection of the light over the lens. The drug was instilled 30 minutes before the examination.

Specular photomicrographs (Figure 2A) of the central area of the cornea of both eyes were obtained. For evaluation, the density, $\left(\right.$ cells $\left./ \mathrm{mm}^{2}\right)$, area $\left(\mu \mathrm{m}^{2}\right)$ of the corneal endothelial cells (DCE), and coefficient of variation $(\%)(\mathrm{CV})$ were considered. The values were transferred to the software CellCount (Figure 2B) for quantitative registration.

\section{Statistical analysis}

The data were submitted to analysis of variance withrepeated measures and the means were compared using the Tukey's test at a 5\% significance level. Data were tested for normality and homogeneity of variance, prerequisites to analysis of variance. The ultrasound time in phacoemulsification between the groups was analyzed by applying the paired $t$ test. The results were considered significant when $\mathrm{P}$ $<0.05$. The tests were conducted using SAS software (Statistical Analysis System). 


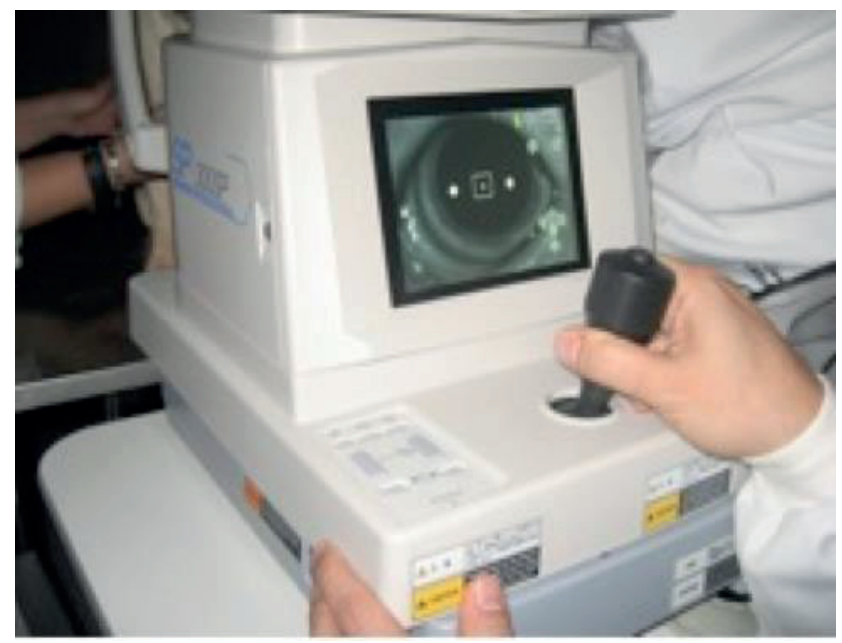

A

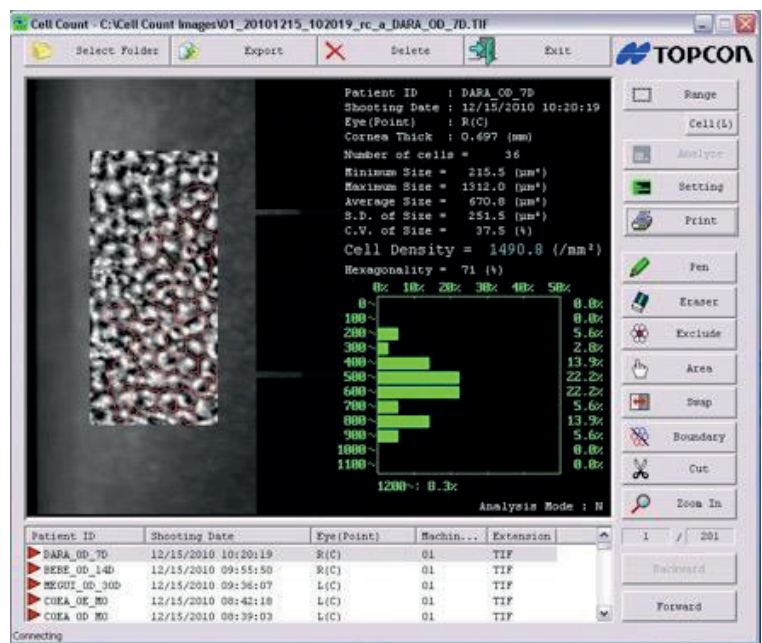

B

Figure 2 - A. Illustrative picture of the procedure during the endothelial cell counting procedure by the non-contact specular microscopy equipment (central corneal area); B. Image of computer screen of count of endothelial cell density (cells / mm2), area ( $\mu \mathrm{m} 2)$ of the corneal endothelial cells (DCE), coefficient of variation (\%) and hexagonality after 7 days postoperative from dog that had mature cataract.

\section{Results}

Dogs of the Poodle breed were the most prevalent in the study $(65 \%, \mathrm{n}=26)$, followed by Lhasa Apso $(15 \%, \mathrm{n}=6)$, Yorkshire $(10 \%, \mathrm{n}=4)$, Maltese $(5 \%$, $\mathrm{n}=2)$ and mixed breed $(5 \%, \mathrm{n}=4)$. As to gender, $65 \%$ were female and $35 \%$ male. The mean age was 5.3 years.

It was possible to perform all surgical interventions, however, with varying degrees of technical difficulty in the execution of each step of phacoemulsification. There was some difficulty performing nucleodissection in both groups, however severe difficulty was encountered in conducting it satisfactorily in fifteen G2 patients (mature), and three G1 patient (immature). Table 1 shows the results of the applied questionnaire in which a higher percentage of technical difficulty is observed in most of the steps of phacoemulsification, mainly in relation to the "V" fracture. There were no cases of posterior capsule rupture, vitreous herniation, dislocation of the lens, retinal detachment, or intraoperative intraocular hemorrhage.

The phacoemulsification time varied between 1.2 and $3.1 \mathrm{~min}$ (mean $2.15 \pm 1.01 \mathrm{~min}$ ) and 2.3 and $4.0 \mathrm{~min}$ (mean $3,16 \pm 1.2 \mathrm{~min}$ ) in the $\mathrm{G} 1$ and G2 patients, respectively. These values differed significantly $(p=0.0223)$. The analysis of quantity of BSS used in the G1 patients was 300 to $600 \mathrm{ml}$ (mean $600 \pm 283.7 \mathrm{~mL}$ ). In the $\mathrm{G} 2$ patients the values ranged from 450 to $650 \mathrm{~mL}$ (mean $900 \pm$ $343,8 \mathrm{~mL}$ ). Statistical analysis revealed differences $(p=0.0445)$ between the groups regarding the same parameter.

Among the clinical variables, discernible visual perception was observed in the immediate postoperative period after the anesthetic effect, which remained for all evaluation periods in patients of both groups. The direct pupillary reflex was absent in all patients 7 days after surgery, returning to normal over the course of time. A moderate degree of photophobia and blepharospasm were observed in the majority of patients in the G1 and G2 in the immediate postoperative period. However, these symptoms abated in intensity as early as seven days after surgery, becoming absent 30 days after in G1 patients and 60 in G2 patients. Despite the existence of the symptoms in both groups, no statistically significant differences were observed between the groups at any evaluation moment. 
Table 1

Frequency distribution of the "Steps of Surgery" variables in dogs with cataract and that were submitted to phacoemulsification by the "V-prechop" nucleodisection technique

\begin{tabular}{|c|c|c|c|c|c|c|}
\hline \multirow{2}{*}{ Step } & \multirow{2}{*}{ Score } & \multicolumn{2}{|c|}{ G1 (Imature) } & \multicolumn{2}{|c|}{ G2 (Mature) } & \multirow{2}{*}{$\mathrm{P}$} \\
\hline & & $\mathrm{N}$ & $\%$ & $\mathrm{n}$ & $\%$ & \\
\hline Corneal incision & None & 21 & 100.0 & 22 & 100.0 & $1,0000^{(1)}$ \\
\hline Auxiliary incision & None & 21 & 100.0 & 22 & 100.0 & $1.0000^{(1)}$ \\
\hline \multirow{2}{*}{ Capsulorexis } & None & 16 & 80.0 & 13 & 60.0 & \multirow{2}{*}{$0.6285^{(1)}$} \\
\hline & Slight & 5 & 20.0 & 9 & 40.0 & \\
\hline \multirow{3}{*}{ "V" fracture } & Slight & 8 & 40.0 & - & - & \multirow{3}{*}{$0.0055^{(1)}$} \\
\hline & Moderate & 10 & 50.0 & 6 & 30.0 & \\
\hline & Severe & 3 & 10.0 & 15 & 70.0 & \\
\hline \multirow{3}{*}{ Hydrodissection } & None & 21 & 100.0 & 17 & 80.0 & \multirow{3}{*}{$0.4737^{(1)}$} \\
\hline & Slight & - & - & 2 & 10.0 & \\
\hline & Moderate & - & - & 2 & 10.0 & \\
\hline \multirow{2}{*}{ Pupilar plane } & Yes & 10 & 50.0 & 4 & 20.0 & \multirow{2}{*}{$0.3498^{(2)}$} \\
\hline & No & 11 & 50.0 & 17 & 80.0 & \\
\hline \multirow{3}{*}{ Phacoemulsification } & Slight & 14 & 70.0 & 11 & 50.0 & \multirow{3}{*}{$0.3413^{(1)}$} \\
\hline & Moderate & 6 & 30.0 & 6 & 30.0 & \\
\hline & Severe & - & - & 5 & 20.0 & \\
\hline Corneal suture & None & 21 & 100.0 & 22 & 100.0 & $1.0000^{(1)}$ \\
\hline
\end{tabular}

(1) Mann-Whitney test

(2) Fisher exact test.

Conjunctival congestion occurred in all animals in the immediate postoperative period. In the G1 animals (immature), eight presented a moderate degree, with regression to light 7 days after surgery, becoming absent from 30 days after. In the G2 animals, a mild degree of congestion was observed seven days after the operation in half the animals and moderate in the other half. The congestion regressed in subsequent periods, becoming absent only at 60 days of follow-up. There was a significant difference between the groups at 14, 21, and 30 days.

A mild degree of diffuse corneal edema was observed in two patients in the G2 (mature) 7 days after surgery, gradually involuting over time. However, corneal edema limited to incisional areas was observed in almost all patients, with regression at the end of the observation period, when there was a discrete leucoma scar, imperceptible due to covering by the upper eyelid. There was no significant difference between groups at any evaluation moment.
For the "flare" the clinical observation was more evident in the $\mathrm{G} 2$ patients. A moderate degree was found in 12 patients in the immediate postoperative period. With time it regressed in the majority of them, persisting in a mild degree in three animals at the end of the observation period. In the G1 patients it was evident from the fifteenth day after surgery, in a mild form, regressing in subsequent periods and becoming absent 60 days postoperatively. Statistical analysis demonstrated differences between the groups studied in the immediate postoperative period and after 30 days of observation.

Chemosis, corneal ulcers, hyphema, hypopyon, and vitreoretinal alterations were not presented at any moment of clinical evaluation in any of the patients. Posterior capsular opacity was observed at the end of the intraoperative period in two G2 patients but did not accentuate with the course of time. 
The values of DCE in the OD (operated) of the animals of the G1 and G2, preoperatively, were $2,379.3 \pm 132.6$ and $2,305.7 \pm 437.7$ cells $/ \mathrm{mm}^{2}$, respectively. When comparing the DCE in the operated eye (OD) with the non-operated (OS) in the G1, there was a significant difference in the immediate postoperative period, and at moments 7 , $14,21,30$, and 45 . In the G2, this difference was observed in the same moments but including 60 days postoperatively.
In the comparison between the operated eyes in the $\mathrm{G} 1$ and $\mathrm{G} 2$, there was a significant difference 30 , 45 , and 60 days after surgery, when the DCE of the G2 reduced significantly $\left(1,750.4 \pm 453.1\right.$ cells $\left./ \mathrm{mm}^{2}\right)$ compared to the G1 $\left(2,347.4 \pm 155.2\right.$ cells $\left./ \mathrm{mm}^{2}\right)$. Table 2 illustrates the mean and standard deviation values of the DCE in the groups at each evaluation moment.

\section{Table 2}

Mean $(\bar{X})$ and standard deviation of endothelial cells density (cells $\left./ \mathrm{mm}^{2}\right)(\mathrm{DCE})$ in patients of the canine species with cataracts that underwent the "V-prechop" technique of nucleodissection by phacoemulsification, according to the study groups and eyes at each evaluation moment

\begin{tabular}{cccc}
\hline \multirow{2}{*}{ Eye } & Moment & \multicolumn{2}{c}{ Endothelial cell density of the cornea $(\overline{\mathbf{x}} \pm \mathrm{s})$} \\
\cline { 2 - 4 } & PRE & G1 Immature & G2 Mature \\
\hline & POI & $2379.3 \pm 132.6 \mathrm{a}$ & $2305.7 \pm 437.7 \mathrm{a}$ \\
Operated & M07 & $2006.6 \pm 165.0 \mathrm{bc}^{*}$ & $1852.9 \pm 583.6 \mathrm{ab} *$ \\
OD & M14 & $1708.4 \pm 363.0 \mathrm{~cd}^{*}$ & $1642.2 \pm 556.6 \mathrm{~b}^{*}$ \\
& M21 & $1394.4 \pm 292.1 \mathrm{~d}^{*}$ & $1403.8 \pm 544.8 \mathrm{~b}^{*}$ \\
& M30 & $1493.6 \pm 240.9 \mathrm{~d}^{*}$ & $1322.6 \pm 234.6 \mathrm{~b}^{*}$ \\
& M45 & $2055.4 \pm 239.1 \mathrm{abcA} *$ & $1571.2 \pm 322.6 \mathrm{bB} *$ \\
& M60 & $2177.1 \pm 211.1 \mathrm{abcA} *$ & $1634.4 \pm 468.0 \mathrm{bB} *$ \\
Control & PRE & $2347.4 \pm 155.2 \mathrm{abA}$ & $1750.4 \pm 453.1 \mathrm{abB} *$ \\
OS & POI & $2383.3 \pm 97.8$ & $2398.4 \pm 262.7$ \\
& M07 & $2312.5 \pm 96.0$ & $2384.1 \pm 212.1$ \\
& M14 & $2401.5 \pm 134.5$ & $2353.6 \pm 264.9$ \\
& M21 & $2395.8 \pm 86.7$ & $2373.3 \pm 217.0$ \\
& M30 & $2425.3 \pm 92.7$ & $2437.2 \pm 186.4$ \\
& M45 & $2370.9 \pm 49.4$ & $2378.2 \pm 158.1$ \\
& M60 & $2385.5 \pm 82.2$ & $2371.5 \pm 130.3$ \\
\hline
\end{tabular}

Legend: $\mathrm{OD}=$ right eye; $\mathrm{OS}=$ left eye; $\mathrm{M}=$ moment; $\mathrm{PRE}=$ pre-operative period; $\mathrm{POI}=$ immediate post-operative period.

Means followed by different letters, lowercase in the column and uppercase in the line, differ from each other through the Tukey test $(\mathrm{P}<0.05)$.

* Significant difference between operated (OD) and control (OS), through the Tukey test $(\mathrm{P}<0.05)$.

As for the $\mathrm{CV}$ of the cell area of the corneal endothelium (\%), there were no significant differences $(\mathrm{P}>0.05)$ between the operated eyes (G1 and G2) compared to the controls (non-operated eyes) in either group or at any moment. However, when comparing the operated eyes of the G1 with the G2 operated eyes, there was a significant difference before the surgical procedures (preoperative moment) compared to the immediate postoperative period and $7,14,21,30$, and 45 days post operatively. 


\section{Discussion}

With the advent of ultrasonic instrumentation in cataract surgery, it is undeniable that techniques have improved and modified. In the present research, we studied, through technical criteria, the "V-prechop" technique of nucleus dissection, as well as its effects on postoperative clinical evolution and the impact of surgery on DCE and intraocular inflammation. The primary reason that motivated us to study this technique, was based on the fact that it demonstrates, in principle, respect for the anatomical details of the lens, allowing preparation of a fragment in a "V", whose fragmentation and aspiration is facilitated. Furthermore, cataracts in dogs present cataractous nuclei with variable degrees of hardness (Slatter, 2005; Munger, 2009), which are not always removable using the "Divide and conquer" technique, faced with trans-surgical complications, such as difficulty with nucleus rotation to perform the second fracture (Akahoshi, 1998; Slatter, 2005; Warren, 2004). Furthermore, due to the technical impossibility, irregular fragments can be created which are free in the anterior chamber, increasing the difficulty in performing emulsification and aspiration and thus the degree of endothelial injury and intraocular inflammation (Munger, 2009; Padua et al., 2017).

The greatest difficulty was in patients with mature cataracts (G2), wherein the inner portion of the nuclei is denser (Akahoshi, 1998). Instead of breaking them, by fashioning a "V", a set of surface lamellae were obtained which were free in the anterior chamber. The complication was less frequent in G1 patients (immature), wherein the nuclei, being less dense, fragmented into two fracture lines, forming the "V" as desired. In medicine there is a consensus indicating early phacoemulsification (Jaffe Jaffe, \& Jaffe, 1990; Akahoshi, 1998; Freitas, 2002; Centurion et al., 2004), which has been adopted in Veterinary Medicine (Wilkie \& Colitz, 2007), as the majority of primary cataracts in dogs will progress to more advanced stages in which the degree of core hardness will be greater (La Croix, 2008).
Nevertheless, we found difficulties in fragmenting the lens in $50 \%$ of patients with immature cataracts (G1) (Table 2). Despite the difficulties, there were no ruptures of the posterior capsule or vitreous prolapses. The incidence of accidents of this nature tends to be lower when using the bimanual technique (Jaffe et al., 2007), as adopted in the present study.

The mean time of ultrasound in patients with immature cataracts (G1) was $3.14 \mathrm{~min}$, higher than reported by Özgencil (2005), in the same type of cataract. This can be attributed to the difficulty in performing the "V" nucleodissection that does not always enable homogeneous and single fragments to be obtained, as is desired. In the present study, the time in patients with mature cataracts (G2) was higher (4.94min), but lower than that reported by the same author. It is a consensus that shorter time is desirable, since the use of too much ultrasound function of the phacoemulsificator can lead to endothelial damage and increased intraocular inflammation (Wilkie \& Colitz, 2007; Munger, 2009; Padua et al., 2017). It should be noted that the statistical analysis revealed significant differences between the groups. The same happened regarding the analysis of quantity of BSS employed. The mean volume used was 600 and $900 \mathrm{~mL}$ for patients in the G1 and G2, respectively. These are comparatively high values compared to those reported by Özgencil (2005) and Martins et al. (2010), who used, on average, $300 \mathrm{~mL}$ in each procedure. The differing values could be attributed to difficulties in nucleofragmentation, resulting in longer phacoemulsification.

The moments chosen for clinical study were adopted based on the evolution of the classic phases of tissue repair. Blepharospasm and photophobia were observed in the initial periods after surgery. Patients in the G1 and G2 presented these signs at moderate intensity in the immediate postoperative period, regressing from day 7 . They were absent in the $\mathrm{G} 1$ patients (immature) after 30 days and in the $\mathrm{G} 2$ after 60 . This is known to be correlated with stimulation of the nerve endings of the epithelium and corneal stroma (Waring, 1984). Conjunctival 
congestion is common in acute conjunctivitis and after intraocular surgery. It begins immediately after trauma or exposure to allergens or toxins so was expected immediately after phacoemulsification (Munger, 2009). There were no postoperative complications identified such as fibrovascular membranes, growth of lenticular fibers, lenticular epithelial membranes, or endophthalmitis (Munger, 2009)

It can be inferred that the presence of immature or mature cataracts does not influence the density values or cell area of the corneal endothelial cells, as the values obtained preoperatively did not differ between the groups and were not as described by Chiurciu et al. (2010) and Pigatto et al. (2006).

The operative procedure caused damage to the corneal endothelium, with decreased cell density, even though viscoelastic were used (cohesive and dispersive) in all patients, with a view to promoting the protection of intraocular tissues, particularly the corneal endothelium (Maár, Graebe, Schild, Stur, \& Amon, 2011). In this sense, the DCE observed in the operated eyes of the G1 patients (immature) differed significantly from the eyes on the nonoperated side at all time points until the $45^{\text {th }}$ day. At 60 days, the DCE returned to baseline values. For the G2 patients (mature), the values differed at all times, with endothelial loss of $24 \% 60$ days after phacoemulsification. The same was described by Chiurciu et al. (2010) and Gwin Lerner, Warren, \& Gum (1983) studying patients who underwent bimanual phacoemulsification (24.97\%) and cataract surgery (22\%), respectively. The cornealendothelium of dogs responds to surgical trauma similarly to that of humans, maintaining the functional monolayer with increased cell size and migration (Mencucci. Ponchietti, Virgili, Giansanti, \& Menchini, 2006). In the G2 there was no alteration in the cell area over time. Endothelial losses described in Medical and Veterinary Ophthalmology are lower than those observed in the present study (Pigatto et al., 2006; Mencucci et al., 2006; Klonowski, Rejdak, \& Alió, 2013; Padua et al., 2017). It is assumed that the degree of cataract development and the nature of the more sophisticated equipment used in phacoemulsification, partly justify this.

Regarding the coefficient of variation, which refers to the cellular polymegathism, variations in values were observed before and in the subsequent moments between the operated eyes of G1 and G2 patients. At 60 days, the values returned to normal, despite the reduction in density, confirming the ability of endothelial cells to increase in size without changing the cell area, as a compensatory mechanism (Pigatto et al., 2006; Schulze et al., 2015).

Despite the possible post-operative complications, such as: fibrovascular membranes, growth in lenticular fibers, lenticular epithelial membranes, and endophthalmitis (Munger, 2009), no such occurrences were identified. Posterior capsular opacity was already evident at the end of the intraoperative period in two patients in the G2; however, this did not evolve temporally. Capsular fibrosis is a common occurrence among dogs with cataracts, being directly related to the age of the patient and stage of development of the cataracts (Wilkie \& Colitz, 2007; Özgencil, 2005; Martins et al., 2010).

Ocular pressure peaks were expected in the first 24 and 48 hours after phacoemulsification (Munger, 2009; Martins et al., 2010). It is assumed that elevation of eye pressure is a postoperative complication and principally related to the viscoelastics (Arshinoff, 2010). There is no doubt that residues of these substances provide mechanical resistance to the aqueous humor flow in the trabecular meshwork (Munger, 2009). The efficient realization of irrigation and aspiration maneuvers (I/A) at the end of phacoemulsification, reduces the intensity of complications (Wilkie \& Colitz, 2007; Nasisse et al., 1991; Warren, 2004; Pigatto et al., 2006). In this sense, it can be assumed that the maneuver was conducted efficiently in all animals, since the IOP remained reduced in the immediate 
postoperative period in all patients included in the study. It remained below normal values in the intermediate evaluation periods, rising from 45 days postoperatively to physiological parameters. It is also assumed that the observed low pressures are related to the use of anti-glaucomatous and postoperative uveitis brought about by the fall in blood aqueous humor barrier (Dziezyc, 1990; Slatter, 2005; Wilkie \& Colitz, 2007; Munger, 2009).

Anti-inflammatory and antibiotic preparations for topical and systemic use collaborate in the control of postoperative uveitis and infection prophylaxis. The frequency and duration of treatment met the recommendations proposed in the literature (Wilkie \& Colitz, 2007; Munger, 2009; Padua et al., 2017). Effectiveness was found in the control of inflammation, proven by the reduction in intensity of evaluated clinical parameters. We chose to conduct the phacoemulsification without implementation of intraocular lenses, as their use introduces a new variable potentially able to interfere in the comparisons we aimed to perform. Dogs do not have the same visual acuity as humans and can live without the correction of refraction, after lens extraction. Therefore, replacement of the natural lens with an artificial one is not imperative (Munger, 2009).

\section{Conclusion}

In conclusion, it can be assumed that the nucleodissection "V-prechop" technique gives rise to performance difficulties in patients with mature cataracts, due to hardness of the nuclei. It is indicated in selected cases of patients with immature cataracts, in which the production of nucleus-linear fragments in a "V" is easier to perform.

\section{Acknowledgements}

São Paulo Research Foundation by financial support (FAPESP): grant \#2009/51337-4.

\section{Bioethics and Biossecurity Committee Approval}

This study was approved by the Committee of Ethics in Animal Experimentation of São Paulo State University (UNESP), School of Agricultural and Veterinarian Sciences, Jaboticabal campus (Protocol: 018663-08).

\section{References}

Akahoshi, T. (1998). Phaco prechop: Manual nucleofracture prior to phacoemulsification. Ophthalmology Techniques of Cataract and Refractive Surgery, (1), 69-91.

Arshinoff, S. A. (1999). Dispersive-cohesive viscoelastic 'soft shell' technique. Journal of Cataract and Refractive Surgery, 25(2), 167-173. doi: 10.1016/ S0886-3350(99)80121-7

Bistner, S. I. (1992). Recent developments in comparative ophthalmology. Compendium Continuing Education in Veterinary Practice, 14(10), 1304-1323.

Can, I., Takmaz, T., Çakici, F., Özgül, M., \& Meltem, M. D. (2004). Comparison of Nagahara phacochop and stop-and-chop phacoemulsification nucleotomy techniques. Journal of Cataract and Refractive Surgery, 30(3), 663-668. doi: 10.1016/j. jers.2003.06.006

Centurion, V., Lacava, A. C., \& Caballero, J. C. (2004). Cirurgia da catarata com microincisão e lente intraocular ultrafina. Revista Brasileira de Oftalmologia, (63), 12-17.

Chiurciu, J. L.V., Brandão, C. V. S., Rodrigues, A. C. L., Ranzani, J. J. T., Ferreira, T. H., Padovani, C. R. (2010). Uso de viscoelásticos na facoemulsificação em cães portadores de catarata: efeitos sobre a pressão intraocular, a morfologia das células endoteliais e a espessura corneana. Arquivos Brasileiros de Medicina Veterinária e Zootecnia, 62 (3), p.570-577, 2010. doi: 10.1590/S0102-09352010000300011

Dziezyc, J. (1990). Cataract surgery. Current approaches. Veterinary Clinics of North American Small Animal Practice, 20(3), 737-754.

Fischer, C. (1989). Geriatric ophthalmology. Veterinary Clinics of North American Small Animal Practice, 19(1), 103-123.

Freitas,M.S.(2002).Nucleodissecção\& facoemulsificação. Arquivos Brasileiros de Oftalmologia, 65(2), 243248. doi: $10.1590 / \mathrm{S} 0004-27492002000200016$ 
Glover, T. D., \& Constantinescu, G. M. (1997). Surgery for cataract. Veterinary Clinics of North American Small Animal Practice, 27(5), 1143-1173.

Gwin, R. M., Lerner, I, Warren, J. K., \& Gum, G. (1982). Decrease in canine corneal endothelial cell density and increase in corneal thickness as function of age. Investigative of Ophthalmology Visual and Science, 22(2), 267-271.

Jaffe, N. S., Jaffe, M. S., \& Jaffe, G. F. (1990). Cataracts surgery and its complications (pp. 400-411). New York, NY: St Louis: Mosby.

Klonowski, P., Rejdak, R., \& Alió, J. L. (2013). Micro incision cataract surgery. Expert Review of Ophthalmology, 4(4), 375-391. doi: 10.1586/17469899.2013.825461

La Croix, N. (2008). Cataracts: When to refer. Topics Compendium Animal Medicine, 23(1), 46-50.

Maár, N., Graebe, A., Schild, G., Stur, M., \& Amon, M. (2011) Influence of viscoelastic substances used in cataract surgery on corneal metabolism and endothelial morphology: comparison of Healon and Viscoat. Journal of Cataract and Refractive Surgery, 27(11), p.1756-61. doi: 10.1016/S0886-3350(01) 00985-3

Martins, B. C., Rodrigues, E. F. Jr., Souza, A. L. G., Almeida, D. E., Brito, F. L. C., Canola, J. C., Brooks, D. E., \& Laus, J. L. (2010). A and B mode ultrasonography in preoperative evaluation of lens and posterior segment of dogs eyes with cataract. Pesquisa Veterinária Brasileira, 30(2), 121-126. doi: 10. 1590/S0100-736X2010000200004

Mencucci, R., Ponchietti, C., Virgili, G., Giansanti, F., \& Menchini, U. (2006). Corneal endothelial damage after cataract surgery: microincision versus standard technique, Journal of Cataract and Refractive Surgery, 32(8), 1351-1354. doi: 10.1016/j. jers.2006.02.070

Munger, R. J. (2009). Catarata. In J. L. Laus (Ed.), Oftalmologia clínica e cirúrgica em cães e gatos (pp.116-132). São Paulo: Editora Roca.

Nafströn, K., Eksten, B., Roselen, S. G., Spiess, B. M., Percicot, C. L., \& Ofrei, R. (2002). Guidelines for clinical electroretinography in the dog. Documenta Ophthamologica, Switzerland, 105(2), 83-92.

Nasisse, M. P. (1991). Phacoemulsification and intraocular lens implantation: A study of technique in 182 dogs. Progress in Veterinary Compendium Ophthalmology, 1(4), 225-232.
Özgencil, F. E. (2005). The results of phacofragmentation and aspiration surgery for cataract extraction in dogs. Turkey Journal of Veterinary and Animal Science, Istambul, 29, 165-173.

Padua, I. R. M., Valdetaro, G. P., Lima, T. B., Kobashigawa, K. K., Silva, P. E. S., Aldrovani, M., Padua, P. P. M., \& Laus, J .L. (2017). Effects of intracameral ascorbic acid on the corneal endothelium of dogs undergoing phacoemulsification. Veterinary Ophthalmology, 21(2), 151-159. doi: 10.1111/vop.12490

Park, S. A., Yi, N. Y., Jeong, M. B., Kim, W. T., Kim, S. E., Chae, J. M., \& Seo, K. M. (2009). Clinical manifestations of cataracts in small breed dogs. Veterinary Ophthalmology, 12(4), 205-210. doi: 10.11 11/j.1463-5224.2009.00697.x

Pigatto, J. A. T., Abib, F. C., Pereira, G. T., Barros, P. S. M., Freire, C. D., \& Laus, J. L. (2006). Density of corneal endothelial cells in eyes of dogs using specular microscopy. Brazilian Journal of Veterinary Research and Animal Science, 43(4), 476-480. doi: 10.11606/issn.1678-4456.bjvras.2006.26462

Resnikoff, S., Pascolini, D., Etya'Ale, D., Kocuri, I., Pararajasegaram, R., Pokhareal, G. P., \& Mariotti, S. P. (2004). Global data on visual impairment the year 2020. Bulletin of the World Health Organization, 82, 844-51.

Schulze, S. D., Bertelamann, T., Mnaojlovic, I., Bodanowitz, S., Irle, S., \& Sekundo, W. (2015). Changes in corneal endothelium cell characteristics after cataract surgery with and without use of viscoelastic substances during intraocular lens implantation. Clinical Ophthalmology, 9, 20732080. doi: 10.2147/ OPTH.S90628

Slatter, D. (2005). Fundamentos de Oftalmologia Veterinária. São Paulo: Editora Roca.

Waring, G. O. (1984). Corneal structure and pathophysiology. In G. O. Waring (Ed.), Corneal disorders: clinical diagnosis and management (pp. 3-25). Philadelphia, EUA: WB Saunders.

Warren, C. (2004). Phaco chop technique for cataract surgery in the dog. Veterinary Ophthalmology, 7(5), 348-351. doi: 10.1111/j.1463-5224.2004.04048.x

Wilkie, D. A., \& Colitz, C. M. H. (2007). Surgery of the canine lens. In Veterinary Ophthalmology (pp. 888931). Iowa, EUA: Blackwell Publishing.

Zhao, L., Chen, X. J., Zhu, J., Xi, Y. B., Yang, X., Hu, L. D.,...Zhang, K. (2015). Lanosterol reverses protein aggregation in cataracts. Nature, 30.523 (7562), 607711. doi: 10.1038 /nature 14650 